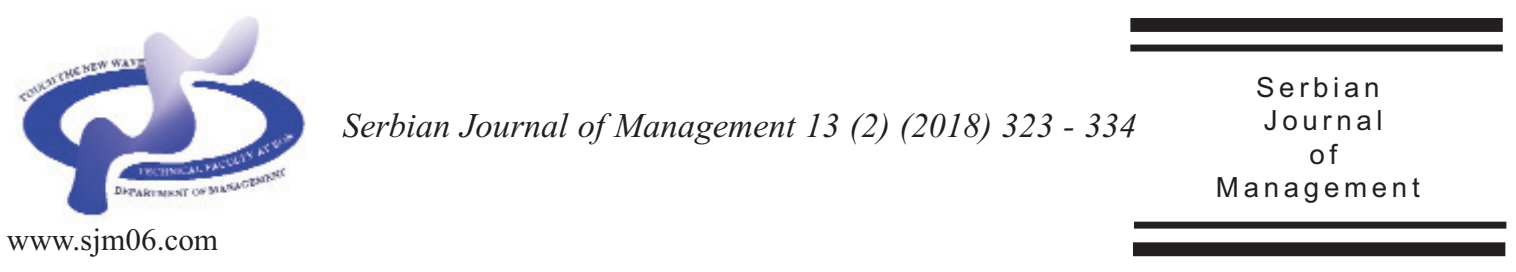

\title{
HOTEL SPA MANAGERS' PERCEPTIONS OF SERVICE QUALITY IN GREECE
}

\author{
Panteleimon Bakirtzoglou $^{\mathbf{a}^{*}}$, Spyridoula Vryoni ${ }^{\mathrm{b}}$ and Panagiotis Ioannou ${ }^{\mathrm{a}}$ \\ ${ }^{a}$ School of Physical Education and Sports Science, \\ Aristotle University of Thessaloniki, Thessaloniki, Greece

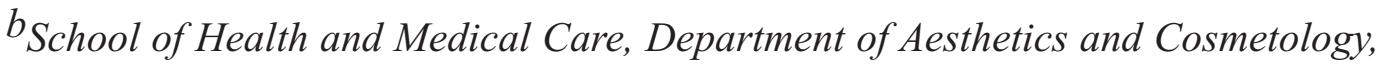 \\ Alexander Technological Institute of Thessaloniki, Greece
}

(Received 13 April 2017; accepted 18 August 2017)

\begin{abstract}
The purpose of the present study was to investigate which dimensions of service quality are most important to Hotel Spa managers for their customers' satisfaction in Greece. Thirty three $(n=33)$ Hotel Spa managers in Greece volunteered to participate in the present study. Measurements included the use of the SERVQUAL instrument (Parasuraman et al., 1988) to measure perceptions of service quality. Factor Analysis (principal component) with Varimax rotation was used to identify the predictive variables of managers' perceptions. The results showed that three variables and four items of SERVQUAL model were the most predictive variables of managers' perceptions. Factors were labeled as follows: Responsiveness, Reliability and Tangibles. Items were labeled as follows: timeliness of Hotel Spa's staff, employees' professionalism, food and beverages and providing promptness service implementation. Those three factors and four items explained Hotel Spa managers' perceptions at the percentage of $50.97 \%$. In conclusion, human (responsiveness and reliability) and environmental (tangibles) factors of service quality are important parameters for Hotel Spa managers in Greece, when they design marketing services aiming to improve their customers' satisfaction.
\end{abstract}

Key words: managers, Greece, hotels, spa, staff, perception

\section{INTRODUCTION}

Wellness tourism is one of the most important and fastest growing markets in the world (Nicolaides \& Grobler, 2017). Global Wellness industry and economy is a $\$ 3.7$ trillion market in 2015, furthermore Global
Wellness tourism grew from $\$ 94$ billion in 2013 to $\$ 563.2$ billion to 2015 . A growth rate more than twice $(6.9 \%)$ as fast as overall tourism expenditures (Global Wellness Institute, 2017).

Wellness can be defined as all the tourists'

\footnotetext{
* Corresponding author: bakirtzoglou@phed.auth.gr
}

DOI:10.5937/sjm13-13687 
activities during or a result of their trip, which are looking for physical, mental, emotional and spiritual positive outcomes and social well-being (Chen et al., 2013; Global Wellness Institute, 2017). According to Smith \& Kelly (2006), Wellness tourism is a holistic travelling style that focus on the development and improvement of the body, mind and spirit.

A Wellness traveler can enhance its personal well-being during his destination in a variety of places such as organic and health restaurants, wellness centers, Spas, baths and spring thalasso, yoga studios, fitness centers, parks and Hotel Spas (Johnston et al., 2011). Traveler's destination has the purpose of maintaining or enhancing personal wellbeing. One of these destinations for a traveler are Spas, moreover Spa tourism has a rapid development (McNeil \& Ragins, 2004) due to the fact that more tourists are looking for an optimal and positive experience during their holidays, which will offer them physical, mental and emotional positive outcomes (Trauer, 2006).

The Global Spa market grew from $\$ 94$ billion in 2013 to $\$ 98.6$ billion to 2015 (Global Wellness Institute, 2017), while according to International Spa Association and its 2016 U.S. Spa Industry Study (ISPA, 2016), total Spa visits were $2.1 \%$ higher in 2015 than 2014. European Spa market has a similar significant increase and has the largest number of Spas worldwide (Spa Global Market Analysis, 2016). In Europe, Greece as a country has a great tradition in the form of Spa tourism (Vasileiou \& Tsartas, 2009). According to Greek Tourism Minister (July, 2016) a new department of thematic forms of tourism (promoting pilgrimage tourism, spa tourism and medical tourism) is being created in Greece.

Spa industry and services have a variety of types and organization form such as fitness spa, salon spa, medical spa, spa resort, mineral-hot springs-natural spa, club spa and hotel spa (Tabacchi, 2010). Spas were traditionally visited not only to obtain medical but also physical, nutrition and mental benefits. In recent years, Spas have become increasingly popular and have emerged as important profit centers for hotels (Koh et al., 2010).

Hotel Spas are one of the most widespread types of Spa industry and tourism (Hsieh et al., 2008). A market research in Switzerland has showed that three to five stars hotels provide to guests wellness facilities such as health information, individual care and a variety of relaxation programs (Mueller \& Kaufmann, 2001). A Hotel Spa usually provides spa services, fitness activities, spa-cuisine menu choices and some wellness components (Madanoglu \& Brezina, 2008). Thus, according to Keri et al (2007) one important criterion for people to their decision when choosing a hotel during their holidays is a hotel which offers spa services.

A Hotel Spa provides services and experiences to guests or customers (Giritlioglu et al., 2014). Its service must adapt to the criteria, demands, needs, interests and customer's expectations. It is important for Hotel Spas to provide quality services in enhancing guests' positive emotions and intention to seek the same experience or service in the future (Lo et al., 2015). A customer will be satisfied if the product or service will meet his or her expectations.

The most widely used and accepted definition of service quality is that provided by Parasuraman et al (1988). Those authors mention that service quality includes five dimensions: tangibility, reliability, 
responsiveness, assurance and empathy. Moreover, dimensions of service quality can be categorized into tangibles and intangibles (Wakefield \& Blodgett, 1999). Tangibles refers to the physical setting or environment and intangibles refers to the human aspect of service delivery such as empathy, reliability and responsiveness of the staff or employees.

High quality of service can result in high customer's satisfaction and increases customer's loyalty (Hapsari et al., 2017; Orel \& Kara, 2014). A Spa should be marketdriven and understand current and future guests (Monteson \& Singer, 2002). Based on this element, many Hotel Spas are paying increasing attention to improve their service quality and enhance customers' satisfaction (Bastic \& Gojcic, 2012).

Hotel's managers have realized the various benefits a Spa facility can bring in terms of hotel revenue (Thorsteinsdottir, 2005). As Alexandris et al (2002) mentioned, the sustainability of clients considered very important issue for service managers. To know and achieve customer's demands, Hotel Spa managers should know which the service expectations of their customers are, and focus on providing higher service quality among customers.

In the Spa market, most of the studies focused on customers' expectations, perceptions and satisfaction about Spa center's service quality (Al-alak, 2012; Alen et al., 2006; Khan \& Tabassum, 2012; Lagrosen \& Lagrosen, 2016; Lo et al., 2015; Snoj \& Mumel, 2002; Tsai, et al., 2012). In Greece, one study has focused in the relationship between customers' satisfaction and Spa centers' service quality (Trihas \& Konstantarou, 2016).

Although service quality in Spa centers has been well researched, there is little comparative research in the area of Hotel
Spas according to managers' perceptions of service quality they provide to guests. Some studies focused on customer's expectations and satisfaction of service quality these Hotels provide (Bastic \& Gojcic, 2012; Blesic et al., 2009; Blesic et al., 2011; Blesic et al., 2014; Hsieh et al., 2008; Lo et al., 2015; Tsai et al., 2012). There are not enough studies concerning and examining the importance from Hotel Spa managers of service quality they provide in relation to their customers' satisfaction.

Therefore the purpose of the present study is to investigate which dimensions of service quality are most important to Hotel Spa managers for their customers' satisfaction in Greece.

\section{METHODOLOGY}

\subsection{Participants}

A total of thirty three $(n=33)$ Hotel Spa managers who attended Hotel Spas from the prefecture of Rhodes island and Halkidiki in Greece, participated in the present study. Demographic characteristics of the sample are presented in Table 1. Out of the total 33 managers, 8 of them $(24.2 \%)$ were males and $25(75.5 \%)$ were females. Their mean age was $29.3(\mathrm{SD}=4.46$ years $)$.

\subsection{Procedure}

Data were collected from managers who attended 33 Hotel Spas, 25 of them in Rhodes island and 8 in the prefecture of Halkidiki (Northern Greece), during September and October 2016. The sample was selected with the method of simple random sampling. A total of 40 questionnaires were distributed and 33 
$(82.5 \%)$ were returned usable for the analysis and the purpose of the present study. Questionnaire was developed based on the SERVQUAL model. Three researchers conducted the survey. All questionnaires were collected through personal interview in which three trained interviewers helped each of the managers answering a written questionnaire. It was emphasized to the participants that the results of the survey will be used for research purposes and that anonymity of the participants will be maintained. The average time spent for filling out the questionnaire was 20 minutes.

\subsection{Data instruments}

The main instrument for data collection was the questionnaire. Managers completed a questionnaire packet containing two sections: the first section included a demographic form (age, gender), and the second section consisted of five dimensions with 22 items designed to measure perceptions of service quality (Parasuraman et al., 1988). For the purposes of the present study, the original 22 items of the questionnaire were translated into Greek and adopted to the Hotel Spa industry on the basis of an extensive literature review.

Service quality was measured by using the variables in SERVQUAL model. Five variables with 22 items from this model were measured as follows: Tangibles with 4 items (appearance of physical facilities and equipment, location of Hotel Spa, food and beverages, price ranges and terms of payment), Reliability with 5 items (ability to perform the promised service, employees' professionalism, employees' knowledge of Hotel Spa's service, availability-clarity and fairness of information, offering services without mistakes), Responsiveness with 4 items (willingness to help the customer, provide promptness service implementation, employees' overload, timeliness of Hotel Spa's staff), Assurance with 5 items (feel secure from danger-risk or doubt, ability of employees to convey trust and confidence, Hotel Spa's image, management support in problem solving situations, friendliness of the employees) and Empathy with 4 items (provision of caring, individualized attention to guest, employees' commitment to the comfort of their guests, honest and empathic treatment of guests).

Responses to each of the 22 items were scored on a 5-point Likert scale ranging from 1 (strongly disagree) to 5 (strongly agree). Reliability of the questionnaire using Cronbach Alpha was calculated at 0.93.

\subsection{Statistical Analysis}

For the purposes of the present study, the statistic package program IBM SPSS Statistics 22.0 version was used. Descriptive statistics were used in order to summarize the mean and standard deviation of variables. Factor Analysis with Principal Component Analysis with Varimax rotation has been used by taking out 22 variables. All factors with eigenvalue greater than 1 and with factor loadings more than 0.3 were retained. Cronbach's $\alpha$ values for each factor were greater than 0.7. Alpha coefficients for each of the five factors ranged from 0.74 to 0.91 .

\section{RESULTS}

The demographic characteristics of the sample are presented in Table 1. The sample of the study consisted of thirty three $(n=33)$ Hotel Spa managers. As it shown, most of the Hotel Spas managers were females 
$(n=25)$, with a mean age of $28.5 \pm 4.4$ years old. Mean age of the male managers $(n=8)$ was $31.8 \pm 3.7$ years old. Total number of the sample had a mean age of $29.36 \pm 4.46$ years old.

\section{Table 1. Descriptive characteristics of} Hotel Spa managers examined as gender and age. Values are presented as mean \pm standard deviation.

\begin{tabular}{ccc}
\hline Participants & Gender & Age \\
\hline Males & 8 & $31.8 \pm 3.7$ \\
Females & 25 & $28.5 \pm 4.4$ \\
\hline
\end{tabular}

Descriptive statistics (mean), standard deviation) of the 22 items are presented in Table 2. Ass it shown most of the items got above average scores (minimum $=1$, maximum $=5$ ).

Table 2. Descriptive statistics of 22 items according to Hotel Spa managers' perceptions.

\begin{tabular}{ccc}
\hline Items & Mean & Sd. Deviation \\
\hline Physical facilities & 4.54 & .79 \\
Hotel Spa's location & 1.81 & .98 \\
Food and beverages & 1.81 & .84 \\
Prices & 4.33 & .88 \\
Perform promised service & 3.96 & 1.10 \\
Employees' professionalism & 4.06 & .99 \\
Employees' knowledge & 2.69 & .58 \\
Fairness of information & 3.51 & .99 \\
Offering services without & 3.63 & .55 \\
mistakes & & \\
Willingness to Help & 4.60 & 1.04 \\
Service's Implementation & 3.81 & .69 \\
Employees' overload & 3.87 & .96 \\
Staffs' timeliness & 3.57 & .87 \\
Secure & 4.27 & .80 \\
Hotel Spa's image & 4.30 & .89 \\
Management's support & 4.21 & .75 \\
Employees' friendliness & 4.45 & .99 \\
Provision of caring & 4.21 & .56 \\
Attention to guest & 4.54 & 1.01 \\
Employees' commitment & 4.27 & 1.08 \\
Honest treatment & 3.66 & .77 \\
\hline
\end{tabular}

In order to measure the appropriateness of the Factor Analysis, the Kaiser-Meyer-Olkin (KMO) measure of sampling adequacy was used. Value of KMO was 0.585 which was an indication of minimum sampling adequacy (Kaiser, 1974) and Bartlett's test of sphericity was significant $(p=0.129)$. As it shown in screen plot (Figure 1), the first four (4) factors explained most of the variability because the line started to straighten after factor 4 .

According to Factor Analysis (Table 3), from the five variables (22 items) of SERVQUAL model, there are 3 significant service quality factors and 4 items for customers' satisfaction according to Hotel Spa managers' perceptions. Those are Responsiveness, Reliability and Tangibles. The eigenvalue of Responsiveness (timeliness of Hotel Spa's staff) was 3.50 which implies that the variance explained by the first factor was $15.94 \%$. Reliability (employees' professionalism) had an eigenvalue of 2.75 and explained the $12.53 \%$ of the total variance. Tangibles (food and beverages) had an eigenvalue of 2.62 and the 11.92 explained of the variance. Responsiveness again (provide promptness service implementation) had an eigenvalue of 2.32 and explained the 10.56 of the variance. Those 3 factors and 4 items could explained Hotel Spa managers' perceptions at the percentage of $50.97 \%$.

Principal Component Analysis with Varimax rotation was used in order to determine the minimum number of factors that would account for maximum variance of Hotel Spa managers' perceptions. As it shown in Table 4, only four items had high factor loadings. Timeliness of Hotel Spa's staff (responsiveness) had a factor loading of 0.822. Employees' professionalism (Reliability) had a factor loading of 0.838 , 
food and beverages (tangibles) had a factor loading of 0.858 , while providing promptness service implementation (responsiveness) had a factor loading of 0.784 .

\section{DISCUSSION}

The purpose of the present study was to examine which dimensions of service quality are most important to Hotel Spa managers for their customers' satisfaction in Greece.
Today, it is widely accepted that service quality has a direct effect on customer satisfaction (Caruana, 2002; Cronin \& Taylor, 1992). Hotel Spa is one of the most widespread type of Spa industry and tourism (Hsieh et al., 2008). One important criterion for people to their decision when choosing a hotel during their holidays is a hotel which offers spa services (Keri et al., 2007). For the majority of service managers, the sustainability of clients is a very important issue (Grönroos, 1984). Thus, Hotel Spa managers should focus how to improve their

\section{Scree Plot}

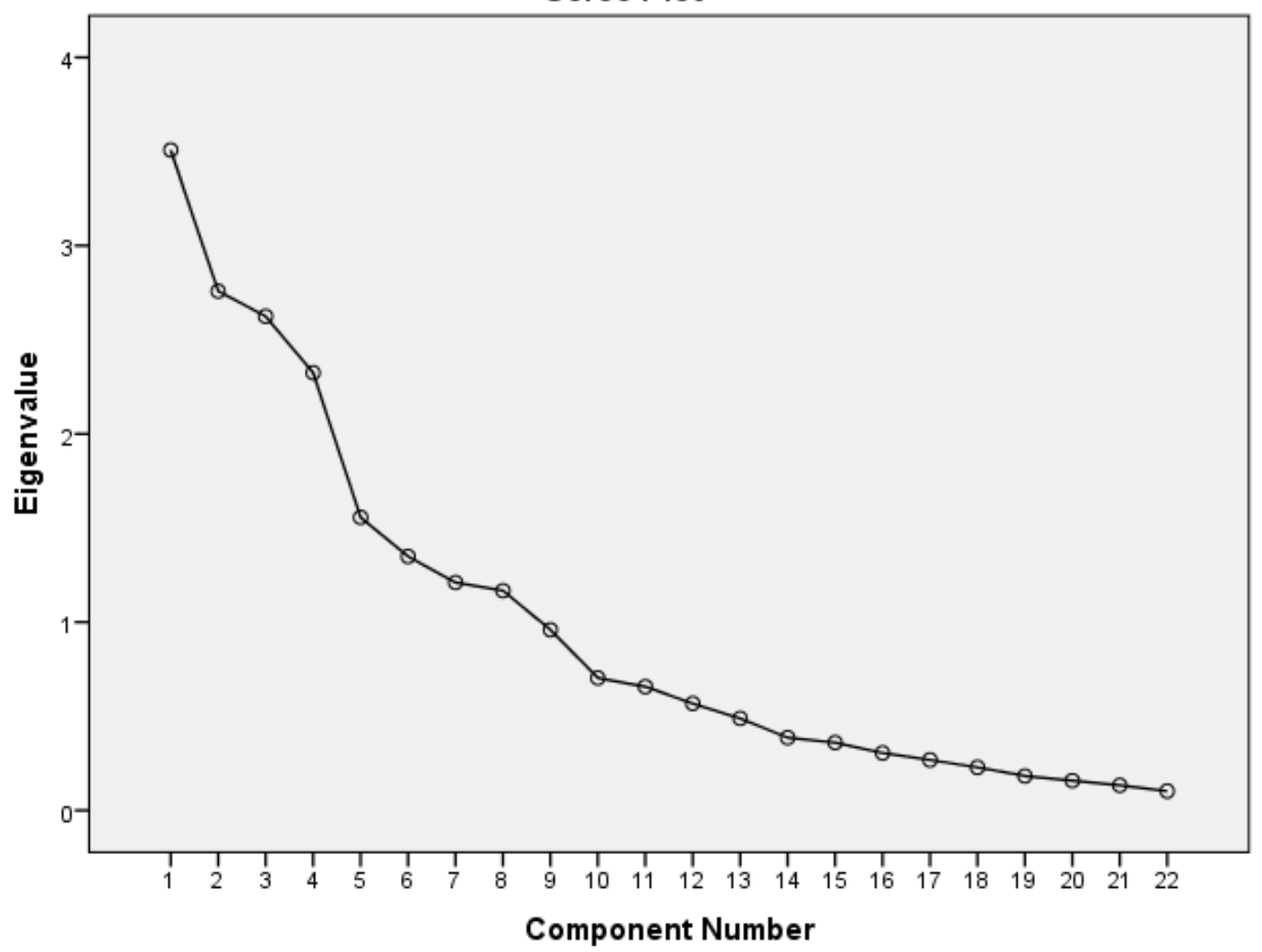

Figure 1. Screen plot of service quality factors according to Hotel Spa managers'perceptions.

Table 3. Total variance explained by the Service Quality's factors.

\begin{tabular}{ccccc}
\hline Factors & Item & Eigenvalue & \% of Variance & Cumulative \% \\
\hline Responsiveness & Staff's timeliness & 3.50 & 15.94 & 15.94 \\
Reliability & Employees' professionalism & 2.75 & 12.53 & 28.48 \\
Tangibles & Food and beverages & 2.62 & 11.92 & 40.41 \\
Responsiveness & Providing service & 2.32 & 10.56 & 50.97 \\
& implementation & & & \\
\hline
\end{tabular}


service quality and enhance their guests' satisfaction (Bastic \& Gojcic, 2012).

In the present study Hotel Spa managers were asked, to which extend SERVQUAL variables are most important for them to their customers' satisfaction. Our results showed that from the five dimensions of the SERVQUAL instrument, only Responsiveness, Reliability and Tangibles were the most significant according to Hotel Spa managers' perceptions. Moreover, items such as timeliness of Hotel Spa's staff, employees' professionalism, food and beverages, and providing promptness service implementation had the highest factor loadings.

Of the five variables of SERVQUAL instrument, Responsiveness (timeliness of Hotel Spa's staff) was the most significant factor for Hotel Spa managers and explained the variance at a percentage of $15.94 \%$.

Also, the fourth significant factor of SERVQUAL instrument according to Hotel Spa managers was again Responsiveness (providing promptness service implementation), contributed at the percentage of $10.56 \%$. Responsiveness has the meaning of willingness to help the guest and provide prompt service (Parasuraman et al., 1988). A survey in Hotel Spas in Serbia has suggested that responsiveness was one of the sevens factors contributed to guests' satisfaction (Blesic et al., 2011). Moreover a survey in Hotel and Resort Spas in China showed responsiveness as the most important determining factor in explaining guests' positive emotions (Lo et al., 2015). Therefore our results are in agreement with the results of the above surveys.

In the present study, Reliability (employees' professionalism) was the second significant factor contributed to Hotel Spa managers' perceptions at the percentage of $12.53 \%$. In Spa market and industry, reliability refers to the ability of Spa's staff or management to provide the reserved service to customers (Parasuraman et al., 1988). This finding is in agreement with the results of

Table 4. Rotated Component Matrix.

\begin{tabular}{|c|c|c|c|c|}
\hline & \multicolumn{4}{|c|}{ Component } \\
\hline & 1 & 2 & 3 & 4 \\
\hline Staffs' timeliness & .822 & & & \\
\hline Employees' knowledge & .735 & & & \\
\hline Attention to guest & .591 & & & \\
\hline Willingness to help & -.585 & & -.476 & \\
\hline Hotel Spa's image & .544 & .431 & & \\
\hline Employees' overload & -.527 & .377 & & \\
\hline Employees' professionalism & & .838 & & \\
\hline Honest treatment & & 699 & & .323 \\
\hline Hotel Spa's location & & .588 & & -.406 \\
\hline Offering services without mistakes & .478 & .559 & & \\
\hline Food and beverages & & & .858 & \\
\hline Employees' confidence & & & .725 & \\
\hline Service's implementation & & & & .784 \\
\hline Perform promised service & & .304 & .454 & .598 \\
\hline Fairness of information & & & -.373 & .595 \\
\hline Prices & & & & \\
\hline Secure & & & & \\
\hline Provision of caring & & & & \\
\hline Employees' friendliness & & & .320 & \\
\hline Management's support & & & & \\
\hline Physical facilities & & & & \\
\hline Employees' commitment & & .406 & & \\
\hline
\end{tabular}


previous surveys indicated the significant contribution of reliability on Spa centers customers' satisfaction (Lo et al., 2015; Blesic et al., 2014; Snoj \& Mumel, 2002).

In our study, Tangibles (food and beverages) was the third significant factor according to Hotel Spa managers' perceptions at the percentage of $11.92 \%$. Tangibles actually refers to Hotel Spa's physical environment of the service (appearance of physical facilities, equipment, food and beverages, appearance of the employees, towels-decoration-tools and Spa's location). This finding is in agreement with the results of surveys which showed that in beauty and Spa centers customers' satisfaction is mainly predicted by tangibles (Al-alak, 2012; Blesic et al., 2014; Khan \& Tabassum, 2012; Tsai et al., 2012; Trihas \& Konstantarou, 2016). Therefore, results of our study indicate the significance for customers' satisfaction according to Hotel Spa managers' perceptions.

According to the results of the present study, it seems that Hotel Spa managers are mainly satisfied from service quality factors such as human and environmental. Human factors or intangible elements of service quality such as Responsiveness and Reliability and environmental factors or tangible elements of service quality such as Tangibles were the most important to Hotel Spa managers on their customers' overall satisfaction at a percentage of $50.97 \%$. Therefore Hotel Spa's management should encouraged to focus its service on those service quality dimensions.

\section{CONCLUSION}

One of the essential areas of marketing theory and practice is service quality, as high quality can enhance customers' satisfaction and motivation. According to Spreng and Mackoy (1996), service quality and customer's satisfaction are two core concepts that are the crux of the marketing theory and practice. Satisfaction is wide concept and is impacted by many factors and service quality is one of the major determinants of customer's satisfactions (Zeithaml \& Bitner, 2003).

In an effort to conceptualize service quality, five factors are critical from the customer's point of view: a) core service or service product $b$ ) human element of service delivery c) non-human element of service delivery d) tangibles or physical quality of service e) social responsibility. The most important aspects of service quality are tangible and intangible (Wakefield \& Blodgett, 1999).

The factor Tangibles or physical quality or physical setting actually refers to elements of service, such as physical appearance, equipment, advertising material and other physical characteristics used for rendering services. Tangible's aspects include building design and décor, ambient conditions and equipment. In Hotel Spa businesses tangibles refers to the external appearance of Hotel Spa's facilities such as appearance of physical facilities, equipment, food and beverages, appearance of the employees, towels-decoration-tools and Spa's location.

Studies showed that tangible aspects have a direct effect on the customer's perceptions of service quality (Wakefield \& Blodgett, 1996, 1999; Wener, 1985). Research in organizational behavior suggest that the physical setting can influence employee satisfaction, productivity and motivation (Sundstrom \& Altman, 1989). According to Bitner (1992), the effect of atmospherics, or physical design and décor elements on 
consumers and workers is recognized by managers and mentioned in marketing and organizational behavioral texts.

On the other side the human element of service delivery or intangibles is one of the key characteristic of services (Wolak et al., 1998). Intangibles refers to elements of service such as the reliability, responsiveness and empathy of the staff or employees. Thus, human factor of services can make the product user friendly and satisfying for the customer.

According to the results of the present study, human and environmental dimensions of service quality are most important for Hotel Spa managers for their customer's satisfaction. Hotel Spa's managers should focus to service's expectations of their guests and to provide higher service quality. Factors such as Responsiveness, Reliability and Tangibles are important for Hotel Spas' managers aiming to improve their customers' satisfaction in Greece. Thus, human and environmental factors are important parameters for Hotel Spa's managers targeting to enhance their guests' satisfaction.

\section{Suggestions}

The present study highlighted the importance and significance of the human (intangible) and environmental (tangible) dimension of service quality according the opinion of Hotel Spa managers for their customer's satisfaction. Therefore the management of Hotel Spas in the future should focus on the human and environmental factor of service it provides for their customer's satisfaction. More emphasis should be given by the Hotel Spa's management to human parameters such as: friendly, empathetic and reliable Hotel Spas' staff and to environmental parameters such as the physical environment of the Hotel Spa (equipment, food and beverages, appearance of the employees, towels-decoration), in an effort to increase its customer's satisfaction.

\section{References}

Al-alak, B.A. (2012). The relationships between service quality, satisfaction, and behavioral intentions of Malaysian Spa center customers. International Journal of Business and Social Science, 3(1), 198-205.

Alen, M.E., Fraiz, J.A., \& Rufin, R. (2006). Analysis of health spa customers' expectations and perceptions: The case of Spanish establishments. Polytechnical Studies Review, 5(6), 245-262.

Alexandris, K., Dimitriadis, N., \& Markata, D. (2002). Can perceptions of service quality predict behavioral intentions? An exploratory study in the hotel sector in Greece. Managing Service Quality: An International Journal, 12(4), 224-231.

Bastic, M., \& Gojcic, S. (2012). Measurement scale for eco-component of hotel service quality. International Journal of Hospitality Management, 31(3), 1012-1020.

Bitner, M.J. (1992). Servicescapes: The impact of physical surroundings on customers and employees. The Journal of Marketing, 56(2), 55-71.

Blesic, I., Ivkov-Dzigurski, A., Stankov, U., Stamenkovic, I., \& Bradic, M. (2011). Research of expected and perceived service quality in hotel management. Journal of Tourism, 11, 5-13.

Blesic, I., Popov-Raljic, J., Uravic, L., Stankov, U., Deri, L., Pantelic, M., \& Armenski, T. (2014). An importanceperformance analysis of service quality in 


\title{
ПЕРЦЕПЦИЈА МЕНАЩЕРА БАЊСКИХ ХОТЕЛА О КВАЛИТЕТУ УСЛУГА У ГРЧКОЈ
}

\section{Panteleimon Bakirtzoglou, Spyridoula Vryoni, Panagiotis Ioannou}

\begin{abstract}
Извод
Сврха ове студије је била да се истражи које су то најважније димензије квалитета услуга за менаџере бањских хотела како би задовољили своје клијенате у Грчкој. Тридесет три (n=33) менаџера бањских хотела у Грчкој добровољно је учествовало у овој студији. Мерења су укључивала употребу "SERVQUAL" методе (Parasuraman et al., 1988) за процену перцепције квалитета услуга. Факторска анализа (главна компонента) са "Varimax" ротацијом коришћена је за идентификацију предикторских варијабли перцепције менаџера. Резултати су показали да су три варијабле и четири ставке "SERVQUAL" модела најнапредивије варијабле перцепције менаџера. Фактори су били означени на следећи начин: одзив, поузданост и материјал. Ставке су означене на следећи начин: правовременост особља бањских хотела, професионалност запослених, храна и пића и пружање брзих услуга. Ова три фактора и четири ставке објашњавају перцепцију менаџера бањских хотела у проценту од $50.97 \%$. Као закључак може се истаћи да је људски фактор (одговорност и поузданост) и фактори окружења (опипљиви фактори) важни параметри за квалитет услуга код менаџера бањских хотела у Грчкој, када дизајнирају маркетиншке услуге са циљем побољшања задовољства својих клијената.
\end{abstract}

Кључне речи: менаџери, Грчка, хотели, бање, особље, перцепција

spa hotels. Economic Research, 27(1), 483495.

Blesic, I., Romeli, J., \& Garaca-Glasnik, V. (2009). An investigation of the expectations of consumers about the quality of services in the spa hotels of West Morava region. Bulletin of the Serbian Geographical Society, 89(1), 103-114.

Blesic, I., Tesanovic, D., \& Psodorov, D. (2011). Consumer satisfaction and quality management in the hospitality industry in South-East Europe. African Journal of Business Management, 5(4), 1388-1396.

Caruana, A. (2002). The effects of service quality and the mediating role of customer satisfaction. European Journal of Marketing, 36(7), 1-14.

Chen, K.H., Chang, F.H., \& Wu, C. (2013). Investigating the wellness tourism factors in hot spring hotel customer service.
International Journal of Contemporary Hospitality Management, 25(7), 1092-1114.

Cronin, J.J., \& Taylor, S.A. (1992). Measuring service quality: re-examination and extension. Journal of Marketing, 56(3), 55-68.

Giritlioglu, I., Jones, E., \& Avcikurt, C. (2014). Measuring food and beverage service quality in spa hotels: A case study in Balikesir, Turkey. International Journal of Contemporary Hospitality Management, 26(2), 183-204.

Global Wellness Institute. (2017). Global Wellness Economy Monitor. January 2017. Available at https://www.globalwellnessinstitute.org/press-room/statistics-and-facts/.

Greek Tourism Minister: Positive 2016 summer season. (2016, July 6). Retrieved from: https:/www.newgreektv.com/englishnews/item/20289-greek-tourism-minister 
positive-2016-summer-season.

Grönroos, C. (1984). A service quality model and its marketing implications. European Journal of Marketing, 18(4), 3644.

Hapsari, R., Clemes, M.D., \& Dean, D. (2017). The impact of service quality, customer engagement and selected marketing constructs on airline passenger loyalty. International Journal of Quality and Service Sciences, 9(1), 21-40.

Hsieh, L.F., Lin, L.H., \& Lin, Y.Y. (2008). A service quality measurement architecture for hot spring hotels in Taiwan. Tourism Management, 29(3), 429-438.

ISPA. (2016). U.S. Spa Industry Study. ISPA Conference \& Expo, September 13.

Johnston, K., Puczkó, L., Smith, M., \& Ellis, S. (2011). Wellness tourism and medical tourism: where do spas fit? New York: Global Spa Summit. Available from: Available from: http://bit.ly/1JzS6oq.

Kaiser, H.F. (1974). An index of factorial simplicity. Psychometrica, 39(1), 31-36.

Keri, K., Ottenbacher, M.C., \& Harrington, R.J. (2007). The North American Spa Industry: An examination of emergent trends. FIU Hospitality and Tourism Review, 25(1), 50-60.

Khan, P.I., \& Tabassum, A. (2012). Service quality and customer satisfaction of the beauty-care service industry in Dhaka: a study of high-end women's parlors. The Journal of Business in Developing Nations, $12,32-58$.

Koh, S., Jung-Eun Yoo, J., \& Boger Jr, C.A. (2010). Importance-performance analysis with benefit segmentation of spa goers. International Journal of Contemporary Hospitality Management, 22(5), 718-735.

Lagrosen, Y., \& Lagrosen, S. (2016). Customer perceptions of quality - a study in the SPA industry. European Business
Review, 28(6), 657-675.

Lo, A., Wu, C., \& Tsai, H. (2015). The impact of service quality on positive consumption emotions in resort and hotel Spa experiences. Journal of Hospitality Marketing and Management, 24(2), 155-179.

Madanoglu, M., \& Brezina, S. (2008). Resort Spas: how are they massaging hotel revenues? International Journal of Contemporary Hospitality Management, 20(1), 60-66.

McNeil, K.R., \& Ragins, E.J. (2004). Staying in the Spa marketing game: Trends, Challenges, Strategies and Techniques. Journal of Vacation Marketing, 11(1), 31-39.

Monteson, P.A., \& Singer, J.L. (2002). Planning and operating a resort-based spa. Journal of Leisure Property, 2(4), 358-368.

Mueller, H., \& Kaufmann, E.L. (2001). Wellness tourism: Market analysis of a special health tourism segment and implications for the hotel industry. Journal of Vacation Marketing, 7(1), 5-17.

Nicolaides, A., \& Grobler, A. (2017). Spirituality, Wellness tourism and quality of life. African Journal of Hospitality, Tourism and Leisure, 6(1), 1-37.

Orel, F.D., \& Kara, A. (2014). Supermarket self-checkout service quality, customer satisfaction, and loyalty: Empirical evidence from an emerging market. Journal of Retailing and Consumer Services, 21(2), 118-129.

Parasuraman, A., Zeithaml, V.A., \& Berry, L.L. (1988). SERVQUAL: A multiple-item scale for measuring consumer perceptions of service quality. Journal of Retailing, 64(1), 12-40.

Smith, M., \& Kelly, C. (2006). Wellness tourism. Tourism Recreation Research, 31(1), 1-4.

Snoj, B., \& Mumel, D. (2002). The measurement of perceived differences in 
service quality - The case of health spas in Slovenia. Journal of Vacation Marketing, 8(4), 362-379.

Spa Global Market Analysis to 2016 \& Forecast to 2020. (2016, April 7). Retrieved from https://www.linkedin.com/pulse/spaglobal-market-analysis-2016-forecast-2020shrikant-rane.

Spreng, R.A., \& Mackoy, R.D. (1996). An empirical examination of a model of perceived service quality and satisfaction. Journal of Retailing, 72(2), 201-214.

Sundstrom, E., \& Altman, I. (1989). Physical environments and work-group effectiveness. Research in Organizational Behavior, 11, 175-209.

Tabacchi, M.H. (2010). Current research and events in the Spa industry. Cornell Hospitality Quarterly, 51(1), 102-117.

Thorsteinsdottir, K. (2005). The state of the European hotel spa sector. Journal of Retail and Leisure Property, 4(3), 272-277.

Trauer, B. (2006). Conceptualizing special interest tourism-frameworks for analysis. Tourism Management, 27(2), 183200.

Trihas, N., \& Konstantarou, A. (2016). Spa-goers' characteristics, motivations, preferences and perceptions: Evidence from Elounda, Crete. AlmaTourism Journal of Tourism, Culture and Territorial Development, 7(14), 17-38.

Tsai, H., Suh, E., \& Fong, C. (2012). Understanding male hotel Spa-goers in Hong Kong. Journal of Hospitality Marketing and Management, 21(3), 247-269.

Vasileiou, M., \& Tsartas, P. (2009). The wellness tourism market in Greece-an interdisciplinary methodology approach. Tourismos: An International Multidisciplinary Journal of Tourism, 4(4), 127-144.

Wakefield, K.L., \& Blodgett, J.G. (1996).
The effects of the servicescape on customers' behavioral intentions in leisure service settings. Journal of Services Marketing, 10(6), 45-61.

Wakefield, K.L., \& Blodgett, J.G. (1999). Customer response to intangible and tangible service factors. Psychology \& Marketing, 9(4), 31-42.

Wener, R.E. (Ed.). (1985). The environmental psychology of serve encounters. Lexington MA.

Wolak, R., Kalafatis, S., \& Harris, P. (1998). An investigation into four characteristics of services. Journal of Empirical Generalisations in Marketing Science, 3(2), 22-41.

Zeithaml, V.A., \& Bitner, M.J. (2003). Services Marketing, 3rd edition, McGrawHill Irwin, Boston MA. 